\title{
ビタミン研究の動向と家畜の栄養
}

佐 橋 佳 一*

副栄養素 accessory food factors の提唱で知られた のは EIJKMAN (1890-7), Hopkins (1906) で, その本 態を濃縮状飞抽出した業績で知られたのは鈴木 梅太郎 (1910) Funk (1911) であろう。この稿を捄引受けする に当り，鈴木博士の研究に協力された島村虎猪博士の功 績に対し，哀心敬意を表する次第である.

昔から科学者は生命の謎を解くことに魅力をもち，い ろいろの研究が行われてきたが，仏の LAVOISIER(1775) が薪の燃觉る現象を見て, 動物の体温, 呼吸の原理を考 兄, BerZelius (1838) が接触化学反応, KÜNE (1875) が澱粉消化醉素反応を研究し, 生物界汇持ける自然の動 的現象の究明に力を注いだのである. その後, 生物の物 質的組成を明確にすることに力が向けられ，生体成分の 有機化学研究が進歩した. ついに生物体内微量成分の追 究となり，ホルモン，ビタミンの発見となったのである が, 今日では酥素の結晶, 抗生物質, ウイルスなどと研 究が進及, 生物の生命に関する諸間題の鍵は開かれよう としてきた.

\section{(1) ビタミン研究の発展と酵素化学の進歩}

生化学泣関する昨今の研究進歩はまこと著しく, 醉 素の衝きは生物の生命の代名詞とまでいきそうである。 しかし酵素も煎じ詰めれば, 生物組成の蛋白質の特殊状 態である. また酵素は蛋白質そのものの特殊状態の久で は活動しえない，これをとりまくいろいろの生体成分が 協力しなければ，その働きは発揮しない。平易な語をか りるならば,酵素は主役で,ビタミンはワキ役となる補酵 素の中にひとむことが多い. 従ってビタミンの化学的研 究のような古典的研究者の努力が全くなかったならば, 今日のような醰素化学研究の盛況には到達し兄なかった ろらと信ぜられる.カルボキシレースの補酵素はビタミ ン $\mathrm{B}_{1}$ の構造決定合成完遂の翌年 (1937), その構造決定 合成を見た事実でも推察される。

\section{(2) ビタミン発見の年表}

ビタミンは水溶性ビタミン（I）扣よび脂溶性ビタミ ン（II）に大別される.

( I ) ビタミン $B_{1}$ 鈴木, FUnK 1910-11, JANSEN1926; ビタミン B ${ }_{2}$ KUHN, KARRER, 1933; ビタミン $B_{6}$ 大岳 1931, 市場 KUHN 1938; ニコチン酸 鈴木 1909;

* 東京農業大学教授〔第 45 回日本臨床獣医学会（関 東）に拈计る講演昭33.6.13]
ニコチン酸アミドＥLVEeHeM, 1938; パントテン酸 Williams, 1919, Woolley, 1938; ビオチン GyöRGYI, 1939; 葉酸 Mitchel, Stockstad, 1941; ビ タミン $\mathrm{B}_{12}$ Rickes, Smith 1948 ; コリン 鈴木 1910；イノシトール WILDIER, 1910； ビタミンL 中原, 鵜上 1945 ; ビタミン $\mathrm{B}_{13}$ オロット酸 NovAK 1948; ビタミンB $\mathrm{B}_{\mathrm{T}}$ カルニチン Fraenkel, CARTer 1953; リポイック酸, チオチック酸 REED, 1951; ビ タミンC GyöRGYI, 1928; ビタミンP GyöRGYI 1936 （II） ビタミンA 高橋 1923, 浜野 1935; カロチン EULeR 1928; ビタミン $\mathrm{D}_{2}$ Windaus, 1936; ビタミ ソD。 Brockman, 1936; ビタミンE Evans, 1936; ビタミンF EVANS 1934; ビタミンK KARRER, DoISY, 1939; ビタミンU Cheny, 1950

\section{（3）各ビタミンと酵素の働き}

\section{(a) 水溶性ビタミン (B 群) 関係}

ビタミン $\mathbf{B}_{1}$ 臨床的には抗脚気因子であるが, 生化学 的にはビタミン $\mathrm{B}_{1}$ のピロ燐酸エステルがピルビン酸, アルファケトグルタール酸などの分解酵素の補酥素とし て働く、酵母では, この補酵素拉よびマグネシウムイオ ンでピルビン酸はアセトアルディイドと $\mathrm{CO}_{2}$ になり， 酒精醗酵の経路に入るが, 他の微生物, 高等動物ではビ タミン $\mathrm{B}_{1}$ ピロ燐酸エステルにニコチン酸アミドを含む 補酵素, DPN, または TPNを必要とする酵素, リポイ ック酸などの協同作用を必要とする複雑な酵素団で生理 作用が完遂され，ピルビン酸は酶酸と $\mathrm{CO}_{2}$ になる。

ビタミン $\mathbf{B}_{2}$ 臨床的汇は抗皮臂炎因子, 抗口角炎因 子であるが, 生化学的汇ばタミン $\mathrm{B}_{2}$ のモノ粼酸エス テルとアデニル酸 AMP 1 分子が結合せる補酵素 FAD 々なり, 酸化還元酵素なるいわゆる黄色酵素の水素受容 体または供与体となり,生体内酸化還元反応汇関与する。 ニコチン酸 臨床的炕抗ペラグラ因子であるが，二 コチン酸アミドとなり,リボース, 燐酸がそれぞれ 1分 子結合し,ビタミン $\mathrm{B}_{2}$ の場合と同様にアデニル酸 1 分子 と結合し, 脱水素酵素の補酵素 DPN, 時にはも51分 子の燐酸がアデニル酸のリボースの 3 位の水酸基洷結合 しTPN となり，上述せる黄色醭素の相手役として水素 の供与体, 受容体となって㗢く.な抢この $\mathrm{B}_{2}$ 扰よび二 コチン酸アミドが協同作用する酸化還元反応注、ささら 鉄を含む酵素チトクローム，へモグロビンなどが後援 する.この現象は時計の歯車が大小か及合って時を刻む

日獣会誌 11 (1958) 
ごとく，1コの歯車の故障でも進行は停止する.

ビタミン $\mathbf{B}_{6} \quad \mathrm{~B}_{1}, \mathrm{~B}_{2}$, ニコチン酸についで発見され た抗皮膚炎因子であるが，これは炭素，水素，酵素の 3 元素化合物と含窒素化合物，とくにアミノ酸との間の代 謝に関係する抗アレルギー因子である. 蛋白質中毒に有 効なのは, この点にあろう. ビタミン $\mathrm{B}_{6}$ は生体内で 3 形態ピリドキシン，ピリドキサール，ピリドサミンに変 化し, これが燐酸と結合し, 補酵素の役目を果すのであ る. 炭水化物の代謝で体内に生じたアルファケトグルタ 一ル酸は, ビタミン $\mathrm{B}_{1}$ のピロ燐酸エステルを補酵素と する酵素で分解されず体内で利用される. この場合の 1 例として, アスパラギン酸のようなアミノ酸とピリドキ サール憐酸エステルを補酵素にもつアミノ基転移酵素で グルタミン酸とオキザール酢酸になる.このオキザール 酢酸はパントテン酸を含む酵素（後述）で，"活性酢酸 根”が結合しクェン酸になりクエン酸サイクルに利用さ れる。またビタミン $\mathrm{B}_{6}$ 燐酸エステルは脸組織でグルタ ミン酸の炭酸基が脱離してガンマーアミノ酪酸になる. すなわちグルタミン酸脱炭酸酵素の補酵素ともなり, 重 要な脳代謝に不可欠のあのとなる. 要するにビタミン $\mathrm{B}_{6}$ の 3 形態はアミノ酸の存在下ならば, 交互に変化しう るのである。

パントテン酸 微生物増殖因子として発見されたが， ビタミン研究の分野としては $\mathrm{B}_{1}, \mathrm{~B}_{6}$, ニコチン酸など を分別除去した，沪過因子と称したエキス状部分の本態 として単離されたビタミンである. その後 LIPMANN, Novelli, BADdiley, Lynen ら (1945-7) の研究で, パ ントテン酸はベーターチオエタノールアミンとアミド結 合し,パントセイン, いわゆるラクトバシルス・ブルガリ クス因子 (L. bulgaricus factor, LBF) となり, さら ルアデノシンと燐酸 3 分子と結合して, "活性酷酸根" 転移酵素の補酵素コーエンザイム $\mathrm{A}$ となり，炭素 2 原子 を生体内で移動させる役目をなすことが明らかにされ た・ピルビン酸の酸化によって生ずる酢酸は,このコーエ ンザイムAによって受取られ，高エネルギー所有のアセ

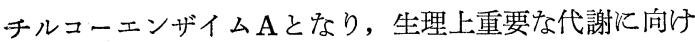
られる.とくに酢酸根はこの酵素で"メチル炭素活性”, “炭酸根炭素活性”いずれにも変じうるので, オキザー ル酷酸に結合してクェン酸生成に向けられるのである. すなわらシトロゲナーゼCitrogenase の補酵素となるの である.また Stern, Ochoa (1951), Gunsalus(1951) によると大臅菌のピルビン酸の脱水素作用により生じた 酰酸は，アセチルコーエンザイムAとなり，さらに無機 嶙酸に反応し，高エネルギー化合物アセチル燐酸塩にな る. KORNBERG (1956) によるとアセチルコーエンザイ ム A は集合して脂肪酸にもなれば，葡萄糖，グリコーゲ ツ生成の資料ともなるＬYNEN（1957）の研究によれば ヌレステロール, ビタミン $\mathrm{A}, \mathrm{D}$, カロチンのごとき
Polyisoprenoid 類は, すべてこのアセチルコーエンザ イムAより生合成されるという。

ビオチン ネズミに生卵を与えて罹る栄養障害を治す 抗卵白障害因子として発見された（1936）が，その後 KÖGL, GYöRGYI, KUHN ら (1939) により微生物増殖に 必須因子との関連性が明確となり，その本態の構造が決 定され, 無機態 $\mathrm{CO}_{2}, \mathrm{NH}_{3}$ に直接つながるアミノ酸, 有 機塩基有機酸生合成の代謝を媒介する酵素に補酵素とし て働くことが明らかにされ，同位元素 $\mathrm{C}^{14}$ を含む重曹 $\mathrm{NaHC}^{14} \mathrm{O}_{3}$ をビオチン負荷のネズミに与光, 体内アスパ ラギン酸,アデニン，クエン酸などに $\mathrm{C}^{14}$ 標識された結 果を観察, その作用機構が説明されるに至った。

葉酸 Minot, Murphy（1926） による抗悪性貧血因 子の研究がそのはじめであるが, MITChEL, STOCKSTAD, Pfiffner(1941-5) により, ビタミン $\mathrm{B}_{\mathrm{C}}$, 葉酸, folic acidの名称をもって有效成分の結晶化, 合成が完成し 臨床的には一応解決がついたが，その作用機構の研究は 最近生化学界に新らしいテーマを提供し, コリン, ベタ イン,メチオニンなどの関与する代謝, すなわちこれら が生理上どんな役割をやるかについてを葉酸の還 元体 folinic acid を補酵素にもつメチル基転移酵素によって 余すところなく説明しうるに至ったのである．炭素 1 原 子は生物体内でこの酵素で運びまわられるのである. メ チル基, フォルムアルデヒド基, 義酸根として葉酸の還 元体 folinic acid いわゆるシトロボラム因子 Citrovorum factor ロイコボリン Leucovorin と複合体を形 成し代謝にあずかる; "活性メチオニン", "活性フォ ルムアルデヒド", "活性義酸"のうち後の 2 者は, こ の複化合物であり, 核酸の塩基, アミノ酸の生合成に役 立つ. コリンはコリン酸化酵素で一応ベタインになり, ベタインは容易に酸化されてナイトロジェンオキサイド の形をとりメチル基は離れやすくなり，ATP,グルタチ オンの存在でメチオニン活性化酵素の作用によって"活 性メチオニン"となり，クレアチン，アドレナリンなど 生体内重要因子の生成を行う．この反応が円滑に回転す るには後述の $\mathrm{B}_{12}$ が不可欠の場合が多い.

ビタミンB 12 $_{12}$ 米 Rickes, 英 SMIth (1948) らにより コバルトを含む赤色結晶としてウシ肝臓，ストレプトマ イセス・グリセウス Streptomyces griseus の培地よ り取り出され $r$ 単位で, ヒトの悪性貧血に有效, シアノ コバラミン Cyanocobalamine と称せられ, 臨床的效果 より一躍ビタミン界の寵児となった。 またこのビタミン は金属元素を含む唯一の高分子ビタミンで酵素の補酵素 として働くより核酸, 補酵素の生体内合成にあずかるの みならず，酵素のアポ酵素生成に役立つことが発見され るに至った. ビタミン $\mathrm{B}_{12}$ が動物蛋白質因子 Animal Protein Factor として発足したのも，この事実などに もよるものと思われよう。 
ビタミン $\mathbf{B}_{13}$ は生化学界でオロット酸 Orotic acidと して知られて和り，ピリミジン核生合成の中間物と確認 されている。

リポイック酸 Lipoic acid は最初 STOckstAD(1949) により発見され，プロトーゲンと名付けられたが，その 後 REED ら (1952) により取り出されたピルビン酸酸化 因子がリポイック酸そのものであった. この作用機構は ビタミン $\mathrm{B}_{1}$ のところで述べたと拉りアポ酵素はピルビ ン酸酸化酵素で, ビタミン $\mathrm{B}_{1}$ ピロ燐酸エステル, DPN コーエンザイムAならびにリポイック酸の 4 者協力の酸 化反応である.

その他のビタミンB群 主要の 2,3 をあげると, コ リンは葉酸の生理に協力し, イノシトールは WILDIER （1910）により酵母增殖因子として抽出されたのである が, 臨床的にはヒトの脂肪肝予防因子 Lipotropic factor として脂肪肝はイノシトールで防止される.

(b) 水溶性ビタミン ( $\mathrm{C}$ 群) 関係

ビタミン C ビタミン B 群以外の水溶性ビタミンとし てアスコルビン酸が知られている.このビタミンは英 DRUMOND(1919)により, 臨床的見地から抗壊血病因子と して発見，穴の後血管の渗透圧を調節する因子としてビ タミンPが発見され，その本態へスペリジン，ルチンな どがビタミンCの作用に協力するという。ビタミンCの 作用機構は周知のよう飞生体内酸化還元に関係し, 水素 伝達酵素系を助ける。かようなわけで SZENT GYÖRGYI (1928) の生体内酸化還元作用の研究中, 副腎から取出さ れ，ヘキシュロン酸と名づけた化合物が, その後TILMAN ら (1932) の研究でC と同一であることがわかり, 構造 決定量産に至ったのである.

(c) 脂溶性ビタミン関係

ビタミンA 臨床的には上皮組織を正常に保つことで 知られ, そのうち最重要なことは視循環生理, すなわち 網膜桿状細胞内視色素視紅が光により視黄になるが, 視 黄はビタミンAアルデヒドの形態なるレチネンと蛋白質 オプシンの結合体である. 網膜内に存するレチネン還元

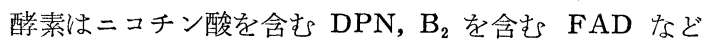
の補酵素の協同作用で, ビタミンAアルコールに戻り視 紅に回収される.この際レチネンは立体有機化学的にシ ス形でなければならず, シス形レチネンはシス形ビタミ ンAに容易に変化しうる。もちろんわれわ机の平素摄取 するビタミンAもシス形でなければならないが, 普通に 知られたるのはオールトランス形である.生物体はこれ を摂取すると直ちにシス形に変じうる力をもち，正常な 生理作用浪のりうるのである. レチネン還元酵素作用に 必要なエネルギーは, 糖, 脂肪の分解による給源によっ てまかなわれる。

ビタミンD Huldschinsky (1919) はクル病研究の 際, 臨床的効果を紫外線に発見し, McCollum (1922) は
肝油中の有効成分, WINDAUS (1927) の研究で不飽和太 テロールがその前駆物質であることが明らかになり，ビ タミンEは生体内防酸化效果物質になることが決定, ビ タミンF脂肪酸酸化酵素深い関係をもち，ことにビ タミン $\mathrm{F}$ 自身が不飽和脂肪酸リノール酸, リノレニン酸 なぞでここれが不飽和化合物の二重結合点を酸化するリ ポオキシダーゼ Lipoxidase の "活性酸素”の伝達体と なる。

ビタミンK 最近上原 (1956) は生体内酸化還元酵素 反応にビタミン $\mathrm{K}_{3}$ が関係することを提唱, ネズミ筋肉 をもってこの実験を行い, 酸化還元酵素の水素伝達体と して衝くことを明らかにした。

\section{(4) 抗ビタミン作用の問題}

ビタミン類が酵素の補酵素などになり作用機構を促進 することは上述のようであるが，自然界には代謝を負方 向に機序するものが存在している.

サイアミナーゼ アノイリナーゼとも称せられる. ビ タミン $\mathrm{B}_{1}$ を分解する酵素で動物, 植物, 微生物などに 広く分布する. 動物界では鯉, 蛤, シジミの生肉, 植物 ではワラビ, ゼンマイ, サッマイモッル,カボチャ, 新鮮 組織果肉, 微生物では腸内細菌, 通称アノイリナーゼ菌 Bacillus thiaminolyticus, Matsukawa et Misawa, Bacillus aneurinolyticus, KimuRa et Aoyamaなどが よく知られている.動物のこの酵素による欠乏はGREEN, Elvenjem(1941) の研究, 狐の Chastek paralysis, 七 ナの生鯉肉食による $\mathrm{B}_{1}$ 欠昂進などで, 微生物によるる のでは新潟県下にあるアノイリナーゼ菌による脚気など がそれである．患者の腸内細菌をスルファミン郕で消滅 しビタミン $\mathrm{B}_{1}$ 内服で効果をあげている.

アスコルビン酸酸化酵素 アスコルビン酸酸化酵素は キウリ, バナナ，チシャ，ホウレンソウなどに広く分布 し, 青緑色蛋白質て銅 $0.24 \sim 0.25 \%$ を含有せる分子量 150,000 のものがよく知られている. 還元型ビタミンC エルアスコルビン酸を酸化型ビタミン $\mathrm{C}$, デヒドロアス コルビン酸とするが, 硫化水素処理で元のビタミンCに 戻る。しかし $\mathrm{pH}$ がアルカリ性に傾けば全解にまで酸化 が進む.

Antagonism ビタミン $\mathrm{B}_{1}$ の Antagonist として知 られているものはピリチアミン, ビタミン $\mathrm{B}_{2}$ に対して はジクロールフラビン,ビタミン $\mathrm{B}_{6}$ の場合は, 4-デスオ キシピリドキシン, ニュチン酸にはイソニコチン酸, パ ントテン酸にはパントイールタウリン, 葉酸には4-アミ ノプテロイールグルタミン酸などである.一般にこれら をアンチビタミンともいう．最近ビタミン $\mathrm{B}_{1}$ にアノイ リナーゼが作用し, または $\mathrm{B}_{1}$ 水溶液の自然分解により 離脱して生ずる2-メチル-5-ヒドロキシメチル-6-アミノ ピリミジン通称トキソピリミジンといわれるものは, 高

日獣会誌 
等動物に対し多量の注射でケイレン死の毒作用を呈する ので, 日本ビタミン学会で問題となり, 医薬上, 生化 学, 薬理学各方面の権威を網羅し慎重検討, 学会誌注揭 載された. トキりピりミジンは4-デスオキシピリドキシ ンと類似構造をもつが, ビタミン $\mathrm{B}_{6}$ の Antagonist で はなく $\mathrm{B}_{6}$ 投与で解毒されない。

\section{（5）ビタミンの資源}

従来ビタミンの資源は天然からあ拉ぐのが常識であっ たが, 現在ビタミン類の大半が化学合成汇成功し量産さ れている. ビタミン $\mathrm{B}_{1}$ をはじめ重要なものは生産過剩 㷧らうとしいる. しかし化学構造の複雑なものの 1,2 点は自然物より抽出, 它しくは微生物尤醱酵 生産法が選ばれている.ビタミン $\mathrm{B}_{12}$ などがその 1 例で 出らう。

ビタミンは生物体内でそれ自体で代謝使われている ものもあるが，むしろ補酵素または補酵素的状態となっ て代謝にあづかる方がはるが多い，最近は研究がこの 補酵素または補酵素的役目を果すと都合のよい形態にし

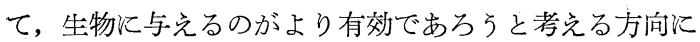
進及, 純学術的研究以外飞飞補酵素を注射, 内服させ上 らといら試みが熾んになってきた。この補醭素負荷につ いてはな打議論の余地が残されている。われわれは普通 の場合, 生体内にビタミンをそのま交觉て動的代謝を 円滑にする仕組を考うるべきであろうと思っている.し かしわれわれは純学究的研究のために必要とするので, 微生物細胞, 動物, 植物の新鮮な子のから補醭素を抽出す ることを研究し，今日では同位元素で標識されたものが 容易に入手でき，これにより吸収效果を測定しうるに至 った。 また生物の体内生産によらないガラス容器内に拉 けるいわゆる生物体外生産汇子研究が進及つつある. こ れらの研究によると補酵素の生成湓高エネルギー化合物 ATP を用い, これを $\mathrm{B}_{1}, \mathrm{~B}_{6}$, パンテセインに組合せそ れぞれビタミン $\mathrm{B}_{1}$ ピロ憐酸エステル(LIPMANN, 1939), ピリドキサール-5-燐酸エステル (Gunsalus, 1944), コ ーエンザイムA（LIPMANN，1951）なぞをえている.最

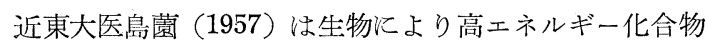
が異るのではないかと研究し, 温血動物では ATP と $\mathrm{B}_{1}$ とでビタミン $\mathrm{B}_{1}$ ピロ燐酸エステルが党られるが, 酵 母のごとき微生物では ITP (Inosine-triphosphate) 李 たは GTP (Guanosine-triphosphate)でないと補酵素 の生成が全く捖こらないことを実験した。この際 IMP (Inosine-monophosphate) むしくは GMP (Guanosine-monophosphate) とわずかの ATP を混合して用 うる時は, そ机ぞれ ITP, GTP の場合と同じく補醭素 生成が行われる. かくしてビタミン類性生物体内核酸の 諸形態と, 各種生物特有の機構により效果を発現してい ることが察せられる.

\section{(6) われわれのビタミン研究の方向}

ウシクワズ病 われわれ研究の着眼点は消化器内微生 物がビタミン学的に健全かどうかであった.ウシは動物 栄養を摂らずして理想的の代謝をやっている，そこにわ れわれに自然が教える微生物の世界, 土壇細菌が高単位 の肝臓成分 $\mathrm{B}_{12}$ を生産しているからである. ウシは土の ままの野草を食し腸内環境にめぐまれて体内酵素の生成 を完遂している．前述せる新潟県アノイリナーゼ菌によ る脚気は患者にスルフォミン剤を与え $\mathrm{B}_{1}$ を投与すれば アノイリナーゼ菌の繁殖は阻止され $\mathrm{B}_{1}$ 吸収は完うされ た. ウシクワズ病地区は水に硅弗化イオンが存在する事 実からウシの保健に不可欠の腸内細菌の死隇に原因があ ろろと直感し詳細研究の結果は, 初期の推定に全く一致 し有用細菌死滅による $\mathrm{B}_{12}$ 欠乏と決定したのである。

トリの $\mathbf{B}_{12}$ 栄養 ニワトリの消化器内はウシと反対 で土壤細菌は全く検出されず, $\mathrm{B}_{12}$ 生産菌生育には不適 当であることを確認した，鶏舎内土壤中からは $\mathrm{B}_{12}$ 高単 位生産菌が分離されているが，これを消化器に故意付 込んでも消えてしまい, ニワトリの消化器内 $\mathrm{B}_{12}$ 生産は 行われないことが確定した.これに反し,アヒルの場合は ウシと同じ消化器内 $\mathrm{B}_{12}$ 生産菌繁殖に好適で, 消化管全 部にわたり高単位生産菌の巣窟であった. 昆虫の世界で はカイコ幼虫はニワトリと類似し, 桑葉に附着せる土壌 細菌 $\mathrm{B}_{12}$ 生産菌は食後 $2 \sim 3$ 時間繁殖し, $B_{12}$ の少量を 生産し消失してしまう。これに反し，土にもぐるコホロ ギはアヒルと酷似し, 体内は $\mathrm{B}_{12}$ 生産菌の巣窟であり, カイコの生体に比し全くけた違いの $\mathrm{B}_{12}$ 保有生体をして いる、すなわち, 虫が土を喰い, 鳥類が虫をついばむ, ウシは土草を食い優良肉を生産する.いずれもかくして 生体内補酵素の生産, アポ酵素の自給自足で健全成長を 行っている.またわれわれはヒナ，ネズミの実験で $\mathrm{B}_{12}$ 欠 乏により $\mathrm{B}_{1}$, ニコチン酸, パントテン酸の結合体が減少 する現象を実験観察したが， $\mathrm{B}_{12}$ 負荷で緩和されること を認めた。この際肝, 筋肉をとり出し, すりつぶし, ピ ルビン酸酸化分解能を調ベると強く低下して拉り，ピル ビン酸分解酵素の活性力が $\mathrm{B}_{12}$ によって生成の左右され る事実を確認したのであるが，このような $\mathrm{B}_{12}$ 欠乏ネズ ミに $\mathrm{Fe}^{55}$ の同位元素標識の鉄を負荷してみると鉄代謝 が極度に落ち, 血色素生成能が衰え, 貧血の原因となっ ていることが実驗された。 また，かような $\mathrm{B}_{12}$ 欠乏のネ ズミの骨髄細胞をとり出し, 滑髄細胞浮游液とし組織培 養を行ってみても $\mathrm{B}_{12}$ をあとから添加したのでは效果を 現わさない，ネズミは生きているうちに $B_{12}$ 老負荷すれ ば骨髄細胞はよく $\mathrm{Fe}^{55}$ を取り入れる力をるつ. 従って この自然界の現象は，われわれに何を教觉てくれている のであろらか驚異の眼で研究心を奮起さすのみである. 